\title{
TEXAS STOCK AND BOND LAW
}

\author{
By Charles Shirley Potts, \\ University of Texas, Austin, Tex.
}

James Stephen Hogg, Governor of Texas from 1891 to 1895, was in many respects the first of the group of progressive leaders of whom Senator La Follette, Theodore Roosevelt and Woodrow Wilson are conspicuous illustrations in more recent times. By his vigorous enforcement of the laws of the state against the railways, as attorneygeneral from 1886 to $1890, \mathrm{Mr}$. Hogg won the reputation that made him the natural leader in the campaign of 1890 , a campaign that ended in the adoption of an amendment to the constitution providing for the establishment of the railroad commission, thus bringing to an end a struggle that had extended over a decade. The legislature that met in January 1891 created the railroad commission and conferred upon it powers that at the time seemed very radical, though not especially so in the light of more recent railway legislation in other states.

\section{Necessity for Regulating the Issue of Securities}

Scarcely had the commission entered upon its duties and promulgated a general system of freight rates before it became evident that for any thorough regulation of rates it would be necessary for the commission to have power to control the issue of railway securities. The necessity for such control was forced upon the attention of the governor and the commission when certain foreign bondholders represented by the Farmers' Loan and Trust Company of Baltimore, went into a federal court and obtained an injunction suspending the rates fixed by the railway commission upon the complaint, among other things, that rates were not high enough to pay the expenses of operation and leave sufficient funds to take care of the interest on the outstanding bonds. "By that action," said Governor Hogg, "the point is sharply, boldly made, that the traffic rates of this country must be maintained to pay the interest on all the railway's bonds. It is material to the public, therefore, that none but honest bonds, 
issued in pursuance and within the limits of the constitution directly, shall be permitted. . . . . Fictitious bonds are not capital nor the representatives of capital. They are the fruits of crime."

With such views as these, Governor Hogg in 1892 offered himself for reëlection upon a platform defending the work of the railroad commission and demanding a law that would place definite restriction upon the power of the railroads to mortgage their property. In his opening campaign speech, he pictured the evils of unrestricted bond issues in the following language:

The railways of this state, according to their sworn reports filed last October with the comptroller, have outstanding against them $\$ 455,250,744$ in stocks and bonds, or an amount more than one-half the assessed valuation of all the property within the state, including the railways themselves; or about $\$ 40,000,000$ in excess of the assessed value of all the lands within the state.

- . . The news goes abroad, and the declaration is commonly made, that there were no railways built in Texas last year; yet during that period they have increased their bonds and stocks to the amount of over $\$ 40,000,000$.

. . . . I know of one road that, within a few weeks after it sold out for $\$ 8,000$ a mile, was mortgaged to secure bonds issued to the amount of $\$ 37,000$ a mile on it. I know another that sold for $\$ 9,500$ cash a mile and was immediately mortgaged to secure bonds for $\$ 35,000$ a mile. Neither of these roads was in the slightest degree improved in equipment or otherwise. There is hardly a road within the state that has not, year by year, increased its bonded indebtedness, until now they nearly all owe quadruple their value. By this illegal process millionaires are made. These roads are rendered for taxation at a valuation of $\$ 63,000,000$, yet their stocks and bonds amount to $\$ 392,000,000$ above that amount. For the last seven years these railways have increased their obligations on an average of $\$ 30,000,000$ annually.

\section{The Stock and Bond Law}

After one of the bitterest struggles in the history of Texas politics, Governor Hogg was reëlected and the following year the present stock and bond law was placed upon the statute books. This law provides for the valuation of all the railways in the state by the railroad commission's engineers and declares null and void any mortgage or lien upon the railway's property in excess of the valuation that is placed upon the roads by the railroad commission. In cases of emergency involving the interests of the public or the preservation of the railway's property, an additional amount of bonds may be authorized, provided that in no case the railroad's outstanding 
stocks and bonds combined shall exceed 150 per cent of the value as determined by the railroad commission. That is to say under ordinary circumstances the bonded indebtedness of the railroads, not including the capital stock, shall not exceed the full value of the property as ascertained by the commission, while 150 per cent is fixed as the maximum limit of both stocks and bonds in cases of emergency.

Two material amendments have been made in the law since its original adoption. One came in 1901 and pertained to the building of branches and extensions and the other in 1907 and authorized the issue of additional securities for the purchase of necessary rolling stock. By the latter amendment the commission was given power to require any railroad to purchase "such rolling stock and motive power as will properly equip such common carrier and facilitate the movement of all traffic," and to allow the issue of securities to pay for the equipment so required.

The amendment of 1901 was adopted to soften a rather too harsh interpretation of the original statute. The commission had held that when a company that was already over-capitalized extended its line by the construction of branches, it could not issue additional securities unless the combined actual value of the road and the extension together exceeded the outstanding securities, and then only an amount equal to the excess could be issued. The amendment of 1901 provided that the commission should allow the issue of new securities up to the total value of the new construction regardless of any formerly existing over-capitalization on the old mileage.

\section{Results of the Law}

It is always a matter of great difficulty to say positively what the results of any given piece of legislation have been. It is very difficult for example to know whether or not the Texas stock and bond law has retarded the building of railways in Texas or has hindered the expenditure of money for improvements and betterments, or has produced any material effect one way or the other on rates and fares. Of one result, however, we can speak with definite assurance, and that is that the law has not only stopped the increase of fictitious stocks and bonds but has actually resulted in a decrease in the average amount of the outstanding securities per mile of line. This result is 
worthy of remark in view of the fact that the last twenty years have seen a marked increase of the outstanding capitalization on the other railroads in the United States. The average amount of capital stock per mile of line in Texas has been reduced from $\$ 15,000$ in 1894 , to $\$ 8,400$ in 1913 , or a decrease of more than 44 per cent. The bonded indebtedness per mile of line has been reduced from $\$ 25,700$ per mile to $\$ 23,200$, or a decrease in the mortgage debt of nearly 10 per cent. The total amount of both stocks and bonds has been reduced from $\$ 40,800$ in 1894 , to $\$ 31,600$ in 1913 , or a reduction of more than 22 per cent.

The following table will show at a glance the changes that have been made in the mileage, in the commission's valuation of the roads, and in the amount of stocks and bonds outstanding, for the years mentioned:

\begin{tabular}{c|r|r|r|r|r|r}
\hline On June 30 & $\begin{array}{c}\text { Mileage } \\
\text { against which } \\
\text { securities were } \\
\text { outstanding }\end{array}$ & $\begin{array}{c}\text { Commis } \\
\text { sion's value outstanding } \\
\text { per mile' }\end{array}$ & $\begin{array}{c}\text { Stock } \\
\text { per mile }\end{array}$ & $\begin{array}{c}\text { Bonds } \\
\text { per mile }\end{array}$ & $\begin{array}{c}\text { Total } \\
\text { stocks and } \\
\text { bonds } \\
\text { per mile }\end{array}$ & $\begin{array}{c}\text { Decrease } \\
\text { per mile }\end{array}$ \\
\hline 1894 & $9,138.22$ & $\$ 15,926$ & $\$ 15,102$ & $\$ 25,771$ & $\$ 40,873$ & $\ldots \ldots$ \\
1898 & $9,284.00$ & 15,748 & 14,596 & 24,699 & 39,295 & $\$ 1,578$ \\
1902 & $10,616.32$ & 15,901 & 12,389 & 21,781 & 34,170 & 5,125 \\
1905 & $11,662.46$ & 16,520 & 10,985 & 21,035 & 32,020 & 2,150 \\
1908 & $12,830.96$ & 17,015 & 10,207 & 20,686 & 30,895 & 1,127 \\
1913 & $15,286.88$ & 18,8242 & 8,409 & 23,206 & 31,615 & $720^{3}$ \\
\hline Total reduction for nineteen years . & $\$ 6,693$ & $\$ 2,565$ & $\ldots \ldots$ & $\$ 9,258$ \\
\hline
\end{tabular}

The figures given in this column are the average for such railroads as the commission had valued up to the dates for which the figures are given.

2 This valuation is taken from the commission's report for the year 1912, but differs only slightly from the figures for 1913 , which are not a vailable at this writing.

Increase.

It should be noted that in addition to the outstanding stocks and bonds, as indicated in the table, the roads owe about $\$ 6,400$ per mile on the indebtedness grouped by the commission under the general headings, "equipment trust obligations" and "current and other liabilities." Nor does the table include some $\$ 18,000,000$ of "certificates of indebtedness" due by the Gulf, Colorado and Santa F6 Railroad Company to the parent company, The Atchison, Topeka and Santa Fe Company. These obligations, however, are not mortgages on the property of the railways, but are presumably obligations that must be met out of the income. 


\section{Need of Revaluation}

While the purposes of the stock and bond law are excellent and its operation has brought very desirable results, there are certain directions in which it is believed modifications of the law either in text or in administration could be made with advantage. In the first place it seems desirable that there should be a general revaluation of the railroads of the state. After the passage of the stock and bond law in 1893 the commission adopted as a basis of valuing the existing roads the cost of reproduction, while for the roads to be constructed in the future the cost of construction was adopted as the principal basis. With reproduction, then, as the basis of valuation, the commission organized a force of engineers, and during the years 1894 to 1896 made a valuation of the existing roads. As new roads have been constructed, they have been valued by the commission, until, at the present time, the commission has valued an aggregate of about 14,000 out of 15,000 miles in the state.

It is believed that a revaluation should be made for the following reasons:

1. The original work of evaluating the roads was hastily and inadequately done. The commission was limited in the number of engineers and accountants, and it felt the need of securing immediate results. As a consequence, the engineers passed over the roads hastily and at best could have made only a superficial estimate of the cost of grading and the value of materials used in construction. The cost of making the original valuations per mile of line was about $\$ 1.50$, whereas the expenditures for similar work in other states has been several times as great, and former Interstate Commerce Commissioner Charles A. Prouty, now in charge of the federal valuation board, estimates that the cost to the government and the roads together of making the valuation of the roads of the country will be about $\$ 25,000,000$, or about $\$ 100$ per mile. The national board has employed a force of 1500 engineers, and 1000 real estate experts, clerks, and stenographers. Compared to the thorough-going inventory thus planned by the federal government, the valuations in Texas seem hopelessly inadequate.

2. In the second place, no allowance has been made for the settling and seasoning of the properties, for the increase in the values of the lands and other properties due to the general growth and 
development of the community, or for the expenditures made for permanent improvements.

3. The values determined in 1896 are unfair to the roads, because they were made at a time when all values were abnormally low. The years 1894 to 1896 were the years when bedrock prices obtained throughout the country and when wages were lower than they had been for twenty years and much lower then they have ever been since. As a result, the values placed by the commission upon rights of way, the rails and ties, and the stations and rolling stock of the roads were such as would not begin to reproduce them in normal times. Probably from 30 to 50 per cent would have to be added to these values to make them -representative of normal prices of materials and rates of wages.

4. Still another reason for a new valuation is to be found in the fact that the existing valuations are surprisingly unequal and unfair. Many of the valuations, as has been stated, were made in the nineties during the period of depression. Others have been made at different times as the roads have been constructed, and, as the cost of material and the rates of wages have varied greatly, the values have shown a corresponding variation. As a result, all the older roads which on account of settling of roadbed and the building up of industrial and commercial relations, one would naturally expect to be the more valuable, are in general valued by the commission at a much lower rate than the newer roads. Thus the Houston and Texas Central, one of the oldest roads in the state, with gross earnings of $\$ 7,449$ per mile, is valued at $\$ 20,500$ per mile, while the Trinity and Brazos Valley not yet ten years old, with an earning capacity of $\$ 5,553$ per mile, is valued at $\$ 29,900$ per mile. In like manner the Gulf, Colorado and Santa Fe, which probably has the best roadbed in the state and has an earning capacity of $\$ 7,320$ is valued at $\$ 17,000$ per mile, while the St. Louis, Brownsville and Mexico, completed about eight years ago, with gross earnings of $\$ 4,706$ per mile, is valued at $\$ 26,000$ per mile. The Galveston, Harrisburg and San Antonio, which is the oldest road in the state, with an earning capacity of $\$ 8,061$ per mile, is valued at $\$ 18,800$ per mile, while the Beaumont, Sour Lake and Western, of recent origin and with an earning capacity of $\$ 6,041$, is valued at $\$ 25,600$ per mile. The Texas and Pacific, the strongest of the Gould roads in Texas, with gross earnings of $\$ 10,200$ per mile, is valued at $\$ 17,000$ per mile, while the International and 
Great Northern, another Gould property, which has but recently passed through a receivership, is valued at $\$ 29,000$ per mile.

Other illustrations could be given, but these are quite sufficient to show the hopeless confusion into which the commission's valuations have fallen, a confusion from which the only escape seems to be a general revaluation of the roads. The results that might be expected from such a revaluation are very well illustrated by the case of the International and Great Northern Railway, referred to above. This road was one of the original roads valued in 1896, and the commission placed a value on its 771 miles of track of $\$ 13,942,000$, or an average value of a little more than $\$ 18,000$ per mile. As a result of the receivership through which the road has passed since 1907, and the consequent reorganization of the company, it became necessary for the commission to revalue the old portion of the road, as well as the additional mileage built since the former valuation, or, as the members of the commission express it, to bring the valuation down to date-a service which the commission stands ready to perform for any road upon request. The result of this work which was completed in June, 1913 , is that the commission now values the road at $\$ 29,097$ per mile. Thus one of the old roads which is not by any means among the best earners or in the best physical condition, has by revaluation had its value as fixed by the commission increased by $\$ 11,000$ per mile, or an increase of 61 per cent. An even more striking result was obtained from a revaluation of the Galveston, Houston and Henderson, by which the commission's values were raised from $\$ 31,000$ per mile to $\$ 63,000$ per mile, or an increase of more than 100 per cent. That changes more or less similar would result from a revaluation of most of the older roads, there is very little reason to doubt.

\section{Bonds for Betterment}

In the second place, it is believed that the law should be so changed as to allow the issue of bonds for extensions and betterments yet to be made. The commission has interpreted the law as authorizing the issue of securities only after the money has been actually spent and the values created. This interpretation compels any road that may desire to make an extension or permanent improvement in its tracks to secure the money first and make the necessary improvements before the bonds will be authorized by the commission, whereas, the ordinary method of financing such improvements is to secure the 
funds first by the sale of the company's bonds. It seems a bit inconsistent to require the company to spend the money first and raise it afterwards. It is contended that this provision of the law as interpreted by the commission has seriously retarded the extension and improvement of the roads by cutting off the one ready source of money supply, namely the use of the corporation's credit.

It is difficult to see any serious objection to allowing the corporations to issue their securities as a means of raising the funds with which to make extensions and betterments, provided always that the commission be given full and complete power to supervise the spending of the money so raised. Such a practice to be sure would result in an increased outstanding indebtedness, but if the commission has power to see that the money is properly expended on the improvements contemplated, this process would not result in an increase of overcapitalization, for every dollar would be used for improving the services or the earning capacity of the property. This modification of the stock and bond law has been introduced in a number of the more progressive states and has everywhere resulted in an improvement of the quality of the service. Thus the California law of 1912 provides that no public utility shall spend the proceeds of the sale of any stocks or bonds or other evidences of indebtedness without first securing an order from the railroad commission, and the commission is given power to require a strict accounting for all moneys so spent. Similar laws are in force in Arizona, Kansas, Wisconsin, New Hampshire, Massachusetts and New York.

\section{Control of Interurbans}

Another change that should be made in the law is to include in its provisions electric interurban railways. Up to the present time these companies have been entirely without regulation either as to rates and fares or as to the issue of securities. It is quite possible that the commission has ample power under the law creating the commission and under the stock and bond law to assume general regulation of interurbans as well as steam railways. These laws give the commission power to "regulate freight and passenger tariffs, to correct abuses, and prevent unjust discriminations and extortion in rates of freight and passenger tariffs on the different railroads in this state" and to authorize the issue of securities for such roads. Interur- 
ban electric roads are certainly railroads and are engaged in carrying freight and passengers. The character of the motive power used by the roads is nowhere referred to in the law, and there would therefore seem to be no reason why the railroad commission should not assume the control of these newer forms of railway facilities. If, however, it be held that the commission has not the power under the present law, the law should be changed so as to bring interurbans under the control of the commission, not only in the matter of rates and fares, but in the issue of securities as well.

\section{Should Refunding be Allowed?}

Still another particular in which the existing law has been criticized is the fact that as interpreted and applied by the railroad commission, it does not permit roads that were over-capitalized at the time the law was passed to refund their maturing bonds. The law, as interpreted by the commission, permits the issue of mortgage bonds only up to the full face value of the property less the amount of the outstanding stock. And where that limit had already been exceeded, the commission will not allow the issue of new bonds in excess of the value of the road, and the difference in the amount of the old and new issues must be provided for in some other way. In case the road should not be able to make such provision, a receivership would be the necessary result.

It is argued by those who favor a change in the law to provide for the refunding of outstanding securities, even though the amount be in excess of the value of the property, that the refunding of the debt would not result in an increase of the mortgage, but would merely be a means of assisting the companies to meet their obligations. They contend further that to refuse to allow the refunding of the bonds would be virtually an impairment of the obligation of a contract, since it would deny to the railroads the means of paying off the obligations that they doubtless had in contemplation at the time the original debt was created. It is also pointed out that the punishment meted out by such a policy would not fall on the shoulders of the guilty parties who are responsible for the over-capitalizing, but upon the innocent purchasers of the bonds, many of whom may have been entirely ignorant of the fact that a wrong was done a quarter of a century before, when the bonds were issued. They point out, too, that the state itself is partly responsible for the over-capitalization, 
because by its negligence and its failure to enact and enforce proper laws, the conditions complained of were allowed to come into existence. For the present, however, this subject is mainly one of academic interest, for up to date no road has been seriously embarrassed by the application of the present rule and no large issues of bonds will be maturing for another ten years. It is probably true, too, that if a thorough-going revaluation of the roads were made it would wipe out the margin of difference between the commission's values and the outstanding securities.

All things considered the conclusion may be safely stated that the Texas stock and bond law has accomplished good results. At the time it was enacted, it was probably the most advanced piece of legislation on the subject in the country, but such has been the veneration in which the law and its great author have been held by the people of Texas that they have feared to tamper with the measure lest its efficiency should be impaired. In fact many of the people of the state have looked with suspicion upon anyone who has had the temerity to propose a modification of the law, fearing lest it be a secret attempt to destroy it. As a result Texas has not kept pace with the progress made in other states and has failed to avail herself of the experience gained by others. Three things at least seem to be fairly clear: first, that there should be a revaluation of the railroads; second, that the commission should be given power to allow the issue of bonds for extensions and betterments, the proceeds to be expended under the commission's supervision; and third, that interurban roads should be brought under the control of the commission in matters of rates and fares, as well as the issue of securities. 